\title{
Ethnobotanical Importance Of Zingiber In The Imphal Valley District, Manipur With Zingiber Chrysanthum Roscoe as A New Record For Manipur.
}

\author{
Ningombam Babyrose Devi ${ }^{1}$, Ajit Kumar Das ${ }^{2}$, P.K. Singh ${ }^{3}$ \\ ${ }^{1,2}$ Department of Ecology and Environmental Sciences, Assam University, Silchar, Assam \\ ${ }^{3}$ Centre of Advanced Study in Life Sciences \\ Department of Life Sciences, Manipur University, Chanchipur, Imphal, Manipur
}

\begin{abstract}
The Zingiberaceae is rich in species used as traditional medicines or spices, but extensive information about their chemistry and pharmacology is available for ginger (Zingiber officinale). Throughout the history of formal ethnobotany, medicinal plants have been an area of keen interest. Zingiber chrysanthum Roscoe has been reported for the first time from Manipur. Detailed description of the plant is provided. The plant was found growing with a small population in the forest margin and foothills of Imphal Valley, Manipur.
\end{abstract}

Keywords: Imphal valley, Manipur, new record, Zingiber chrysanthum

\section{Introduction}

Manipur is situated in the north eastern part of India sharing international boundary with Myanmar. It falls in the Indo-Burma biodiversity hotspot and has its own unique bio-resources of flora and fauna. As a part of Global Biodiversity hotspot and having located in the tri-junction, it has a series of varied topographic distinctions. It has rich floral diversity as well as high degree of endemism. Exploration of the Zingiberaceae at genus and species level in the valley districts is an interesting documentation that could further add to the knowledge of distribution and diversity of taxa and its medicinal value so that further management and conservation measures can be taken up.

The genus Zingiber Mill. is distributed in tropical to warm-temperate Asia with the highest diversity in the monsoonal parts of Asia, particularly in Thailand with 56 species (Triboun 2006) and China with 43 species (Wu \& Larsen 2000) Roxburgh 1810, 1820 reported 11 species of Zingiber in India . Later, Baker 1892 described 24 species from British India. I8 species has been recorded from India (Karthikeyan et al. 1989). Only 4 species has been recorded from Manipur ( Deb 1961) and a new species Zingiber kangleipakense (Kishor et al. 2013) and new report Zingiber roseum ( Devi et al. 2016).

An extensive survey was conducted in Imphal valley district of Manipur, North-east India from 20132015. The Zingiber specimen was observed for the first time in Imphal East district. The area is located at $24^{\circ} 49^{\prime} 21.6^{\prime \prime} \mathrm{N}, 94^{\circ} 04^{\prime} 09.5^{\prime \prime} \mathrm{E}$ at an altitude of $1026 \mathrm{msl}$. Detailed studies were undertaken with the various floras and herbaria and is subsequently identified as Zingiber chrysanthum Roscoe. The collection forms a new distributional record in the Zingiberaceae flora of Manipur. So, the species recorded in Manipur are Zingiber capitatum Roxb., Zingiber chrysanthum Roscoe, Zingiber kangleipakense Kishor \& Skornick, Zingiber montanum (J. Koenig) Link ex A. Dietr., Zingiber officinale Roscoe, Zingiber roseum (Roxb.) Roscoe and Zingiber zerumbet (L.) Sm.

\section{Taxonomic treatment}

Zingiber chrysanthum Roscoe, Monandr. Pl. Scitam.: t. 86 (1824)

Description: Perenial herb; rhizomes fleshy; pseudostem elongate $60-65 \mathrm{~cm}$; leaves entire, oblong - lanceolate, shortly petiolate $0.5-0.6 \mathrm{~cm}$, green, glabrous; pulvinus short, $1-1.5 \mathrm{~cm}$; ligule short, $0.2-0.3 \mathrm{~cm}$; lamina $24-30$ x 7$10 \mathrm{~cm}$, oblong-lanceolate, tip acuminate, glabrous adaxial, abaxially pubescent; inflorescence produced directly borne at the base of the stem, almost buried in the soil; spike $12-14 \mathrm{~cm}$ long, oblong, dense; Bracts reddish, glabrous, obtuse $4 \times 2.5 \mathrm{~cm}$;. Bracteole shorter than the bracts, linear-lanceolate, creamy slightly reddish at the tip ; one flower per bract; flower yellow; calyx tubular $0.8 \mathrm{~cm}$; corolla lobes 3 , apex acute, reddish, one larger and 2 smaller, larger corolla lobe $2.5 \times 0.8 \mathrm{~cm}$, smaller lobes $2.5 \mathrm{~cm} \mathrm{X} 0.5 \mathrm{~cm}$, lateral staminodes fused with the labellum, $2.2 \mathrm{X} 1.5 \mathrm{~cm}$, yellow ; anther innate, crested, $1.2 \mathrm{~cm}$; filament $5.3 \mathrm{~cm}$ long; style white; epigynous glands $2,0.5 \mathrm{~cm}$; ovary villous, $0.3 \mathrm{~cm}$.

Flowering and fruiting: August - November

Conservation status: Not evaluated.

Distributrion: Assam, East Himalaya, Nepal and West- Himalaya 
Ethnobotanical Importance of Zingiber in the Imphal Valley District, Manipur with Zingiber ..

Ethnobotanical uses of the Zingiber species found in Imphal Valley District

\begin{tabular}{|l|l|l|}
\hline Plant species & $\begin{array}{l}\text { Uses } \\
\text { Edible }\end{array}$ & Medicinal \\
\hline Zingiber capitatum Roxb. & --- & Boils, stomach pain. \\
\hline Zingiber chrysanthum Roscoe. & --- & Body pain, gastritis, piles \\
\hline $\begin{array}{l}\text { Zingiber kangleipakense Kishor \& } \\
\text { Skornick }\end{array}$ & $\begin{array}{l}\text { Young tender shoot is used in } \\
\text { preparing eromba dish. }\end{array}$ & --- \\
\hline $\begin{array}{l}\text { Zingiber montanum (J. Koenig) Link ex } \\
\text { A. Dietr. }\end{array}$ & -- & Irregular menstruation \\
\hline Zingiber officinale Roscoe. & $\begin{array}{l}\text { Rhizomes used as spice, pickled } \\
\text { and in preparing ginger tea. }\end{array}$ & $\begin{array}{l}\text { Cough, vomiting, } \\
\text { irregular menstruation. }\end{array}$ \\
\hline Zingiber roseum (Roxb.) Roscoe. & --- & jaundice \\
\hline Zingiber zerumbet (L.) Sm. & --- & Cough, tonsil, constipation \\
\hline
\end{tabular}
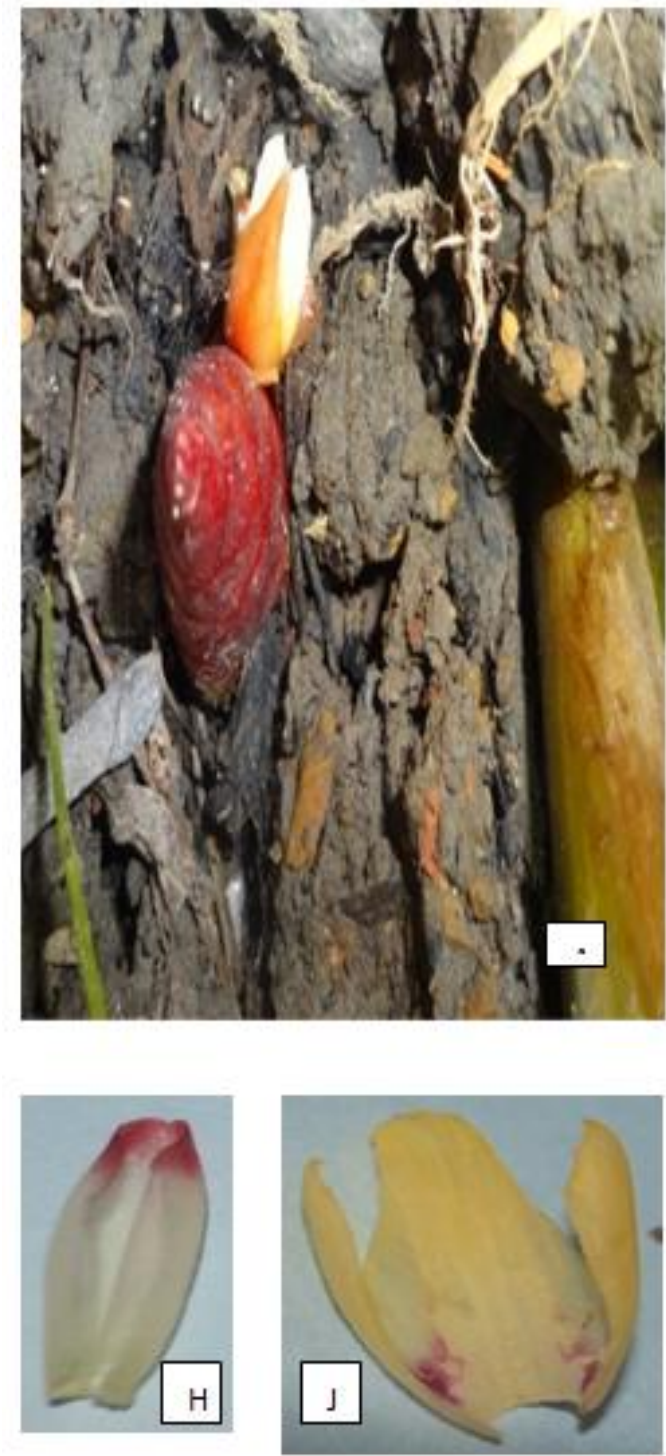

Fig. 1. Zingiber chrysanthum Roscoe. A. natural habit. B. Inflorescence arising from base of the stem. C. single flower. D. dorsal corolla lobe. E. F. lateral corolla lobes. G. anther with crest. H. bracteole I. tubular calyx. J. Labellum fused with staminodes. K. ovary with epigynous glands. 

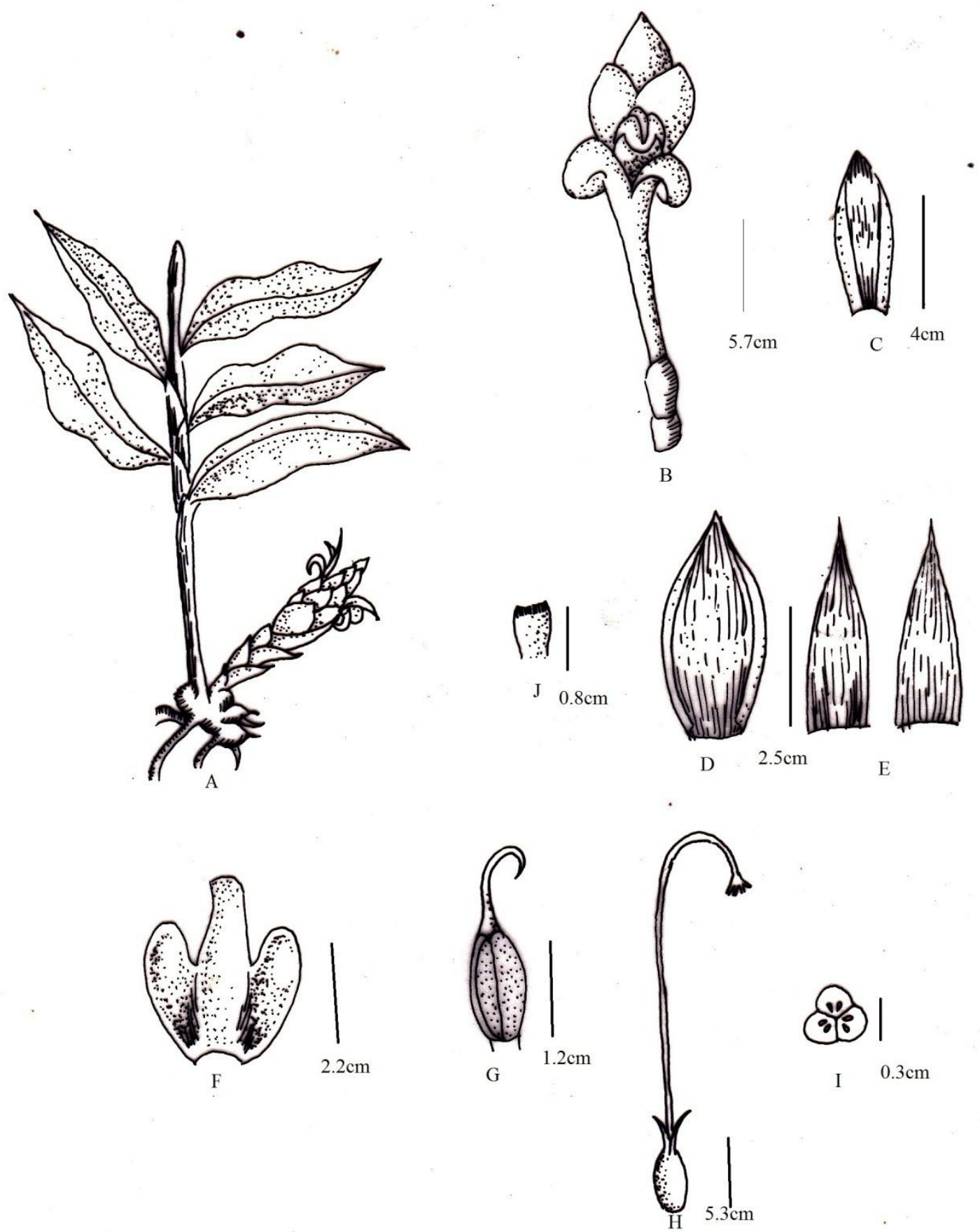

Fig. 2. Zingiber chrysanthum Roscoe. A. natural habit. B. Inflorescence arising from base of the stem. C. bracteole D. dorsal corolla lobe E. lateral corolla lobes F. Labellum fused with staminodes. G. anther crest H. ovary with epigynous glands.I. tricarpelllary ovary

\section{Discussion}

Many research programs in the family Zingiberaceae were reported. Zingiberaceae species are very important in various aspects such as for food, fodder, medicines and economic importance. Different approaches can be employed in the process of bioprospecting also. The plant species of the family Zingiberaceae has a rich source of compounds with interesting biological and pharmacological actions such as Flavonoid and phenolic compounds which were introduced as natural antioxidants. They need to be assessed well for future conservation. Therefore, this research program will give a hint to the researchers and even a layman to protect the Zingiberaceae flora distributed in the valley districts of Manipur. 


\section{References}

[1] Baker, J.G. (1892) Zingiber. In: Hooker, J.D. (ed) Flora of British India 6: 243-249.London: L. Reeve and Co.

[2] Deb, D.B. (1961) Monocot and Dicot plants of Manipur 3: 119-120.

[3] Devi, N.B, Das, A.K., Singh, P.K. (2016). Zingiber roseum (Zingiberaceae): A new record of Gnger from Imphal Valley District, Manipur. Indian Journal of Applied Research, vol 6 (10) : 551-552

[4] Karthikeyan, S., Jain, S.K., Nayar, M.P. and Sanjappa, M. (1989) Zingiberaceae. In:Florae Indicae Enumeratio- Monocotyledonae. 289-299. Calcutta: Botanical Survey of India.

[5] Kishor, R. and Skornickova, J.L. (2013). Zingiber kangleipakense (Zingiberaceae) : A new species from Manipur, India. Gardens' Bulletin Singapore 65 (1): 39-46

[6] Larsen,K. and Delin, W. (2000) Flora of China 24:322-377.

[7] Roxburgh, W. (1810) Description of several of the monandrous plants of India. Asiat. Res. 11: 318-362.

[8] Roxburgh, W.(1820) Flora Indica. Serampore: Mission Press.

[9] Triboun, P. (2006) Biogeography and Biodiversity of the Genus Zingiber in Thailand. PhD thesis submitted to the Graduate school, Khon Kaen University, Thailand. 